\title{
Analysis of Full Time Driver Grab Income Comparison and City Minimum Wage (Case Study in Medan City)
}

\author{
Audrey M. Siahaan ${ }^{\# 1}$, Mei Diana N. Siahaan ${ }^{* 2}$, Victor H. Sianipar ${ }^{\# 3}$, Oloan Simanjuntak ${ }^{\# 4}$ \\ \#1, \#2, \#3, \#4 Department of Accounting, Universitas HKBP Nommensen, Medan, Indonesia
}

\begin{abstract}
This study aims to determine the income of fulltime Grab drivers above or below the UMK applicable in Medan City. Based on the attachment to the Decree of the North Sumatra Governor in Decree Number 188.44 / 674 / KPTS / 2019 to determine the Provincial Minimum Wage and become a reference for determining the City Minimum Wage, the 2020 Medan City Minimum Wage is determined based on the Provincial Minimum Wage reference of IDR 3,222,556.

This type of research is a case study conducted in the city of Medan. This study uses primary data in the form of interviews and questionnaires. Secondary data in the form of regulations on the official Grab website. The questionnaire was given to 60 Grab drivers who were at the grab station. The data analysis method used is descriptive comparative method. The results showed that the net income received by fulltime Grab drivers was above the UMK prevailing in Medan City
\end{abstract}

Keywords - Put your keywords here, keywords are separated by comma.

\section{INTRODUCTION}

In the current era of modernization, the development of digital technology is very rapid with the creation of various digital technology-based business innovations that have an impact on advancing the economy of a country. Digital technology is developing rapidly in the era of the industrial revolution 4.0 marked by the internet of things. There are many things that were unthinkable before suddenly appearing and becoming new innovations, and opening up a very large business area.

With the development of digital technology today, various business fields are developing rapidly, not only in manufacturing companies but also in the digital-based transportation service industry which is currently growing rapidly in Indonesia, this business is growing and developing rapidly in accordance with the demands and developments of digital technology. The transportation industry has an important role in economic development because it is related to the distribution of goods, services and labor and is the core of economic movement.

The development of digital technology encourages changes in the transportation industry around the world, including Indonesia as a country which has more than 17,000 islands with an area of 735,355 square miles in dire need of adequate transportation to support connectivity from one place to another. The type of transportation that is currently being developed is digital / network-based transportation. The main concept of network-based transportation is to create connectivity between passengers and drivers who are connected via the internet.

Infrastructure is the strength of all well-functioning economies in the world. Network-based transportation has been present in Indonesia since 2010 with the operation of several network-based taxi companies such as Go-jek, Grab, Taxi, and Uber. Currently, the development of network-based transportation is in great demand by various people. It has many benefits and advantages since the presence of various online transportation, both in the field of community satisfaction and also in creating jobs. One of the popular onlinebased transportation is Grab.

Grab is one of the online transportation services that is in great demand by the public from the various features offered and the promos provided. Grab is a company from Malaysia that serves transportation provider applications and is available in six countries in Southeast Asia, namely Malaysia, Singapore, Thailand, Vietnam, Indonesia and the Philippines. Grab is available to meet the needs of people in urban areas, solutions to avoid traffic jams, solutions for those who do not have private vehicles, such as students or company employees. With Grab, everyone can travel more easily. The Grab application can be downloaded on smart phones that have iOS and Android operating systems. In addition, the Grab application utilizes electronic media, 
so that it can facilitate access to ordering motorcycle taxi services. Grab will pick up its customers and take them to their destination according to the consumer's order listed on the smart phone application. Not only for shuttle, Grab also provides various other services such as Grab-Food which can deliver food from anywhere according to consumer orders. Grab Express, which delivers goods anytime and anywhere and there are many more features provided by Grab Indonesia.

In addition, the presence of Grab can help improve the people's economy. At this time being a grab driver is in great demand by various groups, even many students also work side-by-side as grab drivers. Those who work as Grab drivers / drivers can have additional income by utilizing the vehicles and android cell phones they have. The advancement of information and communication technology aims to make grab drivers more productive and earning. With online transportation services, it will make it easier for drivers to accept and complete orders. With increasing competition in getting jobs, becoming a Grab Driver can be an alternative job for those who don't have a permanent job. Being a Grab Driver has the advantage of being independent of working hours and the amount of income that depends on the number of orders completed. The daily income of a Grab Driver is greatly influenced by many things such as: The amount and distance traveled in completing orders, bonuses, commissions, operating hours, and costs incurred.

Working with this flexible time, it is possible that there will be many people who want to join as grab drivers. It is possible for permanent employees in a company to change their profession to become Grab drivers. This can also be due to the potential income offered is higher than their previous job. The monthly income to become a Grab driver that you get may exceed the City Minimum Wage (UMK), especially the City Minimum Wage (UMK) that applies in the city of Medan. The North Sumatra Provincial Minimum Wage in Decree Number 188.44 / 674 / KPTS / 2019 stipulates the Provincial Minimu Wage of IDR 2,499,423 in 2020, the Governor of Sumatra Decree regarding the Provincial Minimum Wage is a reference in the preparation and determination of the Regency / City Minimum Wage (UMK) ) in North Sumatra for 2020, where the Medan City Minimum Wage (UMK) is set at IDR 3,222,556.

By looking at the phenomenon in recent years, the Indonesian transportation world has been surprised by the emergence of digital-based transportation companies. The start-up company succeeded in disrupting the mass transportation business that was previously controlled by only a handful of companies. The conditions for joining were easy with a promising income, at that time it was used to attract motorcycle taxi drivers and private car owners to do their vehicle business. Medan City is one of the areas where the community is not very familiar with motorcycle taxis, usually people are small micro-entrepreneurs by pulling rickshaws, rental vehicles and public transportation, but with the emergence of online motorcycle taxis, namely grabbing people's mindset changes, some parties such as pedicab drivers, car rentals and even employees companies, switching to business their vehicles using the Grab application which is currently rife in the community, the factor that drives people to switch is that income is more promising and can even compete with UMK.

\section{Problem Formulation and Problem Limitation}

Based on the background that has been stated above, the problem can be formulated: How is the income of a full time Grab Driver when compared to the City Minimum Wage?

Limitation of the problem is needed to limit the scope of research, due to limited time, funds and manpower. In order for this research to be more focused and not too broad the scope of the discussion, the researchers only focused on research around the HKBP Nommensen University which is in the East Meadan District.

\section{III.LITERATURE REVIEW}

Income is often called revenue. Income and gains are components of income. The principles of income define things such as the understanding and components of income, the measurement of income, and about when revenue is recognized and about when it is measured. There are 3 (three) types of interpretation of the concept of income, namely: (a.) Revenue is the net asset inflow that is generated by the seller of goods and services-inflow concept; (b.) Revenue is the cash flow out of goods or services from the company to its customers - the outflow concept; (c.) Revenue is a company product that results from the creation of goods or services by the company in a certain period - product concept.

Income can be classified into 3 parts: (1.) Salary and Wages. Rewards that are earned after that person has done work for someone else that is given in one day, one week or one month; (2.) Income from own business. It is the total value of the production output minus the costs paid and this business is a self-owned or family business and the labor comes from the family members themselves, the value of the rent for own capital and all these costs are usually not considered; (3.) Income from other businesses. Income is earned without 
exerting energy and is usually a side income, including income from renting out assets such as houses, livestock and other goods, interest from money, contributions from other parties and income from retirement.

\section{Grab Driver Income}

Grab is one of the largest online transportation service companies in Indonesia, which has many regular consumers. Due to the large number of services used by consumers, there are wide opportunities to register as a Grab driver. Regarding the income of a grab driver, it is adjusted to the target passenger per day, if a grab driver exceeds the target passenger, he will get a bonus or incentive. The bonus that you get is adjusted to the job that has been done.

Driver grab revenue uses a profit sharing system which can be calculated as follows, $10 \%$ for the company and $90 \%$ for the driver, this is certainly not detrimental. The more requests for services received will have a direct impact on the income earned. In knowing the Grab Driver's income, it will relate to the rates that must be paid by consumers. The Grab fare will automatically appear when the passenger has entered the pick-up location and destination location because the Grab fare is determined by the distance traveled. The income earned from the driver is in the form of incentives per trip and revenue sharing from Grab fares. The income per trip is guaranteed by the grab party so that every driver will get it as long as it meets several conditions, namely:

- To get an incentive or bonus, the driver must have met the number of trips or trips found, if it does not reach the target then the incentive will not apply

- If the driver has a lot of trips and working hours, the incentive guarantees will be even more

- Grab will pay the difference between the incentives provided

- The profit sharing system between the driver and Grab is $10 \%$ of the Grab fare scheme, for the remaining $90 \%$ belongs to the company.

To be able to find out the calculation of Grab, you must first know the tariff scheme. Of course the important thing to note is the working day and the guarantee of the argument. For working days, Monday to Friday, it has certain rates at certain hours which do vary. As a grab driver, you must be smart to see opportunities by taking jobs that have a higher tariff value. Of course there are 2 types of tariff schemes, namely Grab Red and White, where both have differences in additional jobs. If you use the red grab option, drivers will automatically take more jobs to achieve incentives per day. The red grab option also has a total hotspot with a metered guarantee, while the white grab option doesn't.

On the official Grab website, it is known that the Grab fare calculation is as follows: the meter is IDR 11,000 to IDR 13,000 for trips under $6 \mathrm{~km}$ and an additional IDR 2,300. As for how to see the details of the incentives, you can directly via the Grab Driver application. The following is a simulation of Grab driver revenue in 2020:

$\square$ Divers work within 20 days Monday to Friday full time with a trip distance of $140 \mathrm{~km}$ per day or you can say $10 \mathrm{~km}$ per one trip

$\square$ Drivers work from 08.00 to 10.00 , afternoon 12.00 to 14.00 and night 16.00 to 19.00

The estimated number of hours per trip is 2 trips with a target of 14 trips per day

The total trip time in one day is 280 minutes or you can say 20 minutes per trip

The number of trips really affects the grab driver's income. With the example of the above criteria, we can immediately simulate the calculation of the Grab driver for one month's income (see table 1). With the Grabbike calculation criteria above, the driver will get an income of IDR 6,892,000 (see figure 1).

Table 1 Calculation of Grabbike's Monthly Income

\begin{tabular}{|c|c|}
\hline $\begin{array}{l}\text { Grab Bike merah } \\
\text { Total rate per day } \\
\text { Total rate per month } \\
\text { Profit sharing } \\
\text { Total incentives per day } \\
\text { Total incentives per month } \\
\text { Total Income }\end{array}$ & 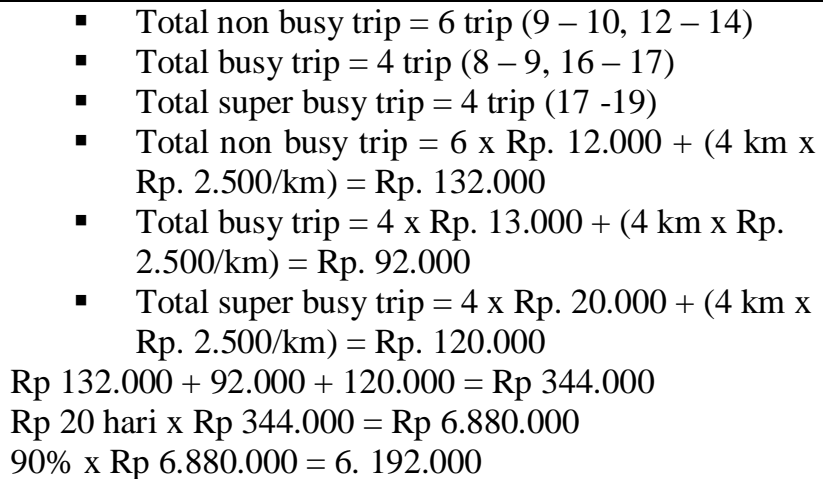 \\
\hline
\end{tabular}


DOI: $10.51386 / 25815946 /$ ijsms-v3i6p108

\begin{tabular}{|l|l|}
\hline & Rp 35.000 (14 trip) \\
& $\operatorname{Rp~35.000~} 20=\operatorname{Rp} 700.000$ \\
& Rp 6.192.000 + Rp 700.000 = $\mathbf{6 . 8 9 2 . 0 0 0}$ \\
\hline
\end{tabular}

Source: www.grab.com

Figure 1: Example of Calculating Incentive for Grab Food and Combined

\section{Insentif GrabFood dan Gabungan,} Diluar GrabBike \& GrabExpress:

1. Bonus per trip GrabFood (tanpa potongan) : Rp 10.000

2. Bonus mingguan GrabFood (tanpa potongan):

- 5 trip :Rp 30.000

- 10 trip : Rp 60.000

- $>15$ trip : Tp 100.000

3. Bonus gabungan per hari GrabFood + GrabBike + GrabExpress Senin-jumat (tanpa potongan):

- 10 trip : Rp 15.000

- 15 trip : Rp 20.000

- 20 trip : Rp 60.000

- $>25$ trip : Rp 150.000

4. Bonus gabungan per hari GrabFood + GrabBike + GrabExpress Sabtu-Minggu (tanpa potongan):

- 10 trip : Rp 20.000

- 16 trip : Rp 70.000

.$>21$ trip : Rp 120.000

Source: www.grab.com

Figure 2: Example of Total GrabFood Driver Income Calculation

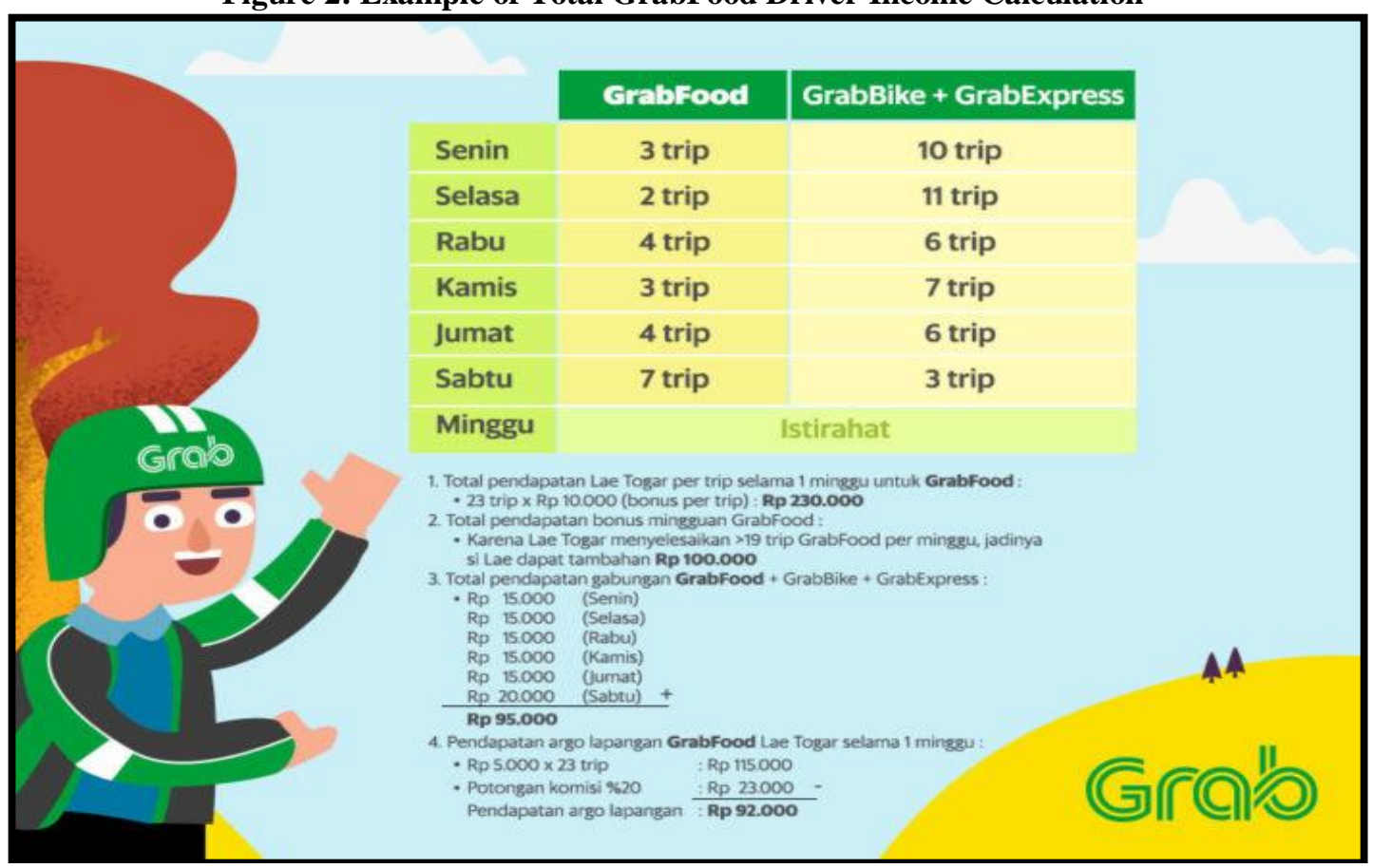

Source: $w w w . g r a b . c o m$

So if the total income of the Grabfood Driver in 1 week is IDR 517,000, this does not include the incentives for Grab Bike and Express. 


\section{DOI: $\underline{10.51386 / 25815946 / i j s m s-v 3 i 6 p 108}$}

Volume: 3 Issue: $6 \quad$ November to December 2020

www.ijsmsjournal.org

Figure 3: Example of Grab Driver Income Calculation

\begin{tabular}{|c|c|c|c|c|c|}
\hline \multicolumn{2}{|l|}{ GrabFood } & \multicolumn{2}{|l|}{ GrabExpress } & \multicolumn{2}{|l|}{ GrabBike } \\
\hline Jumlah Order GF & $\begin{array}{c}\text { Jarak } \\
\text { tempuh }\end{array}$ & Jumlah Order GE & $\begin{array}{c}\text { Jarak } \\
\text { tempuh }\end{array}$ & Jumlah Order GB & $\begin{array}{l}\text { Jarak } \\
\text { tempuh }\end{array}$ \\
\hline Order ke 1, Pendapatan Rp 15.000 & $5 \mathrm{~km}$ & Order ke 1, Pendapatan Rp 15,000 & $8 \mathrm{~km}$ & Order ke 1, Pendapatan Rp 10.000 & $7 \mathrm{~km}$ \\
\hline Order ke 2, Pendapatan Rp 15.000 & $4 \mathrm{~km}$ & Order ke 2, Pendapatan Rp 20.000 & $10 \mathrm{~km}$ & Order ke 2, Pendapatan Rp 10.000 & $7 \mathrm{~km}$ \\
\hline Order ke 3, Pendapatan Rp 15.000 & $6 \mathrm{~km}$ & Order ke 3, Pendapatan Rp 15.000 & $8 \mathrm{~km}$ & Order ke 3, Pendapatan Rp 15.000 & $9 \mathrm{~km}$ \\
\hline Order ke 4, Pendapatan Rp 15.000 & $6 \mathrm{~km}$ & \multirow[t]{4}{*}{ Order ke 4, Pendapatan Rp 15.000} & \multirow[t]{4}{*}{$7 \mathrm{~km}$} & Order ke 4, Pendapatan Rp 15.000 & $9 \mathrm{~km}$ \\
\hline Order ke 5, Pendapatan Rp 15,000 & $5 \mathrm{~km}$ & & & Order ke 5, Pendapatan Rp 10.000 & $7 \mathrm{~km}$ \\
\hline \multirow[t]{2}{*}{ Order ke 6, Pendapatan Rp 15.000} & \multirow[t]{2}{*}{$3 \mathrm{~km}$} & & & Order ke 6, Pendapatan Rp 10.000 & $7 \mathrm{~km}$ \\
\hline & & & & Order ke 7, Pendapatan Rp 20.000 & $14 \mathrm{~km}$ \\
\hline \multicolumn{2}{|l|}{ Jumlah Pendapatan Rp 90.000} & \multicolumn{2}{|l|}{ Jumlah Pendapatan Rp 65.000} & \multicolumn{2}{|l|}{ Jumlah Pendapatan Rp 85.000} \\
\hline
\end{tabular}

Source: www.grab.com

\section{Hours of Work Theory}

In human life, there are always various activities. One of these activities is manifested in movements called work. Work means carrying out a task that ends with a work that can be enjoyed by the human being concerned. Working in a broad sense can be defined as carrying out an activity in a narrow sense, namely carrying out an activity to produce something or money. There are many things that encourage people to work. One of them is to make ends meet. People work hard because there are things they want to get. One of the most important things is money. Where in today's difficult times people are competing to work hard to get money to make ends meet.

Working hours are the time to do work, it can be done during the day and / or at night. Planning the jobs that will come are steps to improve time management. The number of workers employed depends on the need, either to keep up with market demand or to maintain a constant workforce. Both have consequences on labor costs (labor cost).

A Grab driver does not have a fixed working hour like an employee at a company. So that some drivers have their own various ways and set the time each order takes. There are no rules in a day that require a minimum of 7-8 hours and 5 or even 6 days of work a week.

This is what makes drivers can be classified into 2 groups based on working hours, namely: Full time Grab drivers and Grab Part time drivers. Full time Grab drivers are assumed to work 7 to 8 hours and 5 or 6 working days a week. Meanwhile, part time Grab drivers have less time than working full time, usually per day only takes 3 to 5 hours. The starting hours of a driver are very flexible, drivers are free to choose to work from morning to evening or from noon to night.

\section{Wages}

Wages are workers / laborers' rights that are received and expressed in the form of money as remuneration from the entrepreneur or employer to workers / laborers who are determined and paid according to a work agreement, agreement or statutory regulation, including allowances for workers / labor and their families for a work and services that have been or will be performed.

With this wage system, workers are paid based on working time, for example daily, weekly, or monthly. The amount of wages can also be determined based on the amount of time spent completing a job. An example is overtime pay which is calculated on overtime hours worked. The monthly wage is generally applied to the type of continuous work performed by permanent employees at the company. They receive wages in the form of salaries and benefits on a regular basis, usually at the end or at the beginning of each month. This type of employee wages also applies to employees on a fixed-time work agreement (PKWT) that is made based on a certain period of time, namely a maximum of 2 years. Meanwhile, daily wages are more often applied to daily casual workers, whose number of working days is less than 21 days a month, and are only paid when employees come to work.

Employers do not pay employees for work based on working time, but rather the quantity of work output is determined based on units of calculation, for example per piece, per seed, per kilo, per dozen, per score, and the like. So, for the same job, the amount of wages received by each worker can be different every month, or depending on the productivity of each. In principle, the more work that is successfully completed, the greater the wages you will get.Examples of the application of the unit wage system are Small and Medium Enterprises (UKM), for example the convection, handicraft and food industries. This wage system also applies to types of freelance work such as translators who are paid per page and freelance journalists who are paid per news (report). 


\section{Overview of Minimum Wages}

Government Regulation Number 78 of 2015 concerning Wages regulates the issue of minimum wages. According to this PP, the Governor determines the minimum wage as a safety net. The minimum wage as referred to is the lowest monthly wage which consists of: (a.) Wages without allowances; (b.) The basic wage includes a fixed allowance.

Regency / City Minimum Wage is the Minimum Wage that applies in a Regency / City area. District / City Minimum Wage is determined by the Governor, which must be higher than the provincial minimum wage, which is determined every 1 year and is determined not later than 40 (forty) days before the date the minimum wage comes into effect, which is every 1 January. Determination of district / city minimum Wages as referred to in Article 46 PP. 78 of 2015 is calculated based on the formula for calculating the minimum wage. The formula for calculating the minimum Wage as referred to is as follows:

$\mathrm{UMn}=\mathrm{UMt}+\{\mathrm{UMt} \mathrm{x}($ Inflasit $+\% \Delta \mathrm{PDBt})\} 34$

Note: UMn: Minimum wage to be determined.

UMt: Minimum wage for the current year. Inflasit: Inflation calculated from the period September last year to the period September of the current year.

GDPt: Gross Domestic Product growth calculated from the growth of Gross Domestic Product covering the third and fourth quarters of the previous year and the first and second quarters of the current year.

The 2020 Regency / City Minimum Wage for all districts / cities has been set by the Governor of North Sumatra, EdyRahmayadi, and takes effect from January 1, 2020. Previously, the Governor of North Sumatra, EdyRahmayadi, had asked the Regency / Pemko to immediately submit the 2020 UMK proposal through a Circular of the Governor of North Sumatra. Number 561/10838/2019 concerning the Results of the Evaluation of the Determination of the UMK 2019 and the Preparation for the Determination of the UMK 2020 dated 21 October 2019. The Governor of North Sumatra in the Decree of the Governor of North Sumatra Number 188.44 / 674 / KPTS / 2019 stipulates that the UMP of North Sumatra 2020 has been IDR 2,499,423 UMP North Sumatra has increased by 8,51\% of the 2019 UMP figure, is a reference for determining the 2020 UMK for districts / cities and PP Number 78 of 2015 concerning Wages, while the following is a list of Regency / City Minimum Wages (UMK) for North Sumatra 2020:

Table 2 Calculation of Grabbike's Monthly Income

\begin{tabular}{|c|c|c|}
\hline Provinsi & District / Municipality & Tahun 2020 \\
\hline \multirow[t]{22}{*}{ North Sumatera } & Medan City & Rp 3,222,556 \\
\hline & Deli SerdangDistrict & Rp 3,118,592 \\
\hline & AsahanDistrict & $\operatorname{Rp} 2,814,734$ \\
\hline & Binjai City & $\operatorname{Rp} 2,614,781$ \\
\hline & DairiDistrict & $\operatorname{Rp} 2,504,195$ \\
\hline & HumbangHasundutanDistrict & $\operatorname{Rp} 2,524,032$ \\
\hline & KaroDistrict & $\operatorname{Rp} 3,070,354$ \\
\hline & DistrictLabuhanBatu & $\operatorname{Rp} 2,895,289$ \\
\hline & DistrictLabuhanbatu Selatan & $\operatorname{Rp} 2,930,970$ \\
\hline & DistrictLabuhanbatu Utara & $\operatorname{Rp} 2,869,292$ \\
\hline & Simalungun & $\operatorname{Rp} 2,607,089$ \\
\hline & DistrictLangkat & $\operatorname{Rp} 2,710,988$ \\
\hline & DistrictMandailing Natal & $\operatorname{Rp} 2,691,808$ \\
\hline & DistrictNias & $\operatorname{Rp} 2,560,336$ \\
\hline & City Padang Sidempuan & $\operatorname{Rp} 2,676,209$ \\
\hline & CityPematangSiantar & $\operatorname{Rp} 2,501,519$ \\
\hline & DistrictSamosir & $\operatorname{Rp} 2,648,577$ \\
\hline & DistrictSerdangBedagai & $\operatorname{Rp} 2,869,291$ \\
\hline & DistrictBatu Bara & Rp 3.191.571 \\
\hline & CityTanjungbalai & $\operatorname{Rp} 2,822,425$ \\
\hline & DistrictTapanuli Selatan & $\operatorname{Rp} 2,903,042$ \\
\hline & DistrictTapanuliUtara & $\operatorname{Rp} 2,542,836$ \\
\hline
\end{tabular}




\begin{tabular}{|l|l|l|}
\hline & DistrictTapanuli Tengah & $\mathrm{Rp} \mathrm{2,830,884}$ \\
\hline & District Toba Samosir & $\mathrm{Rp} \mathrm{2,668,614}$ \\
\hline & DistrictGunungSitoli & $\mathrm{Rp} \mathrm{2,668,614}$ \\
\hline & District Padang Lawas & $\mathrm{Rp} \mathrm{2,735,827}$ \\
\hline & District Padang Lawas Utara & $\mathrm{Rp} \mathrm{2,767,874}$ \\
\hline & DistrictTebingTinggi & $\mathrm{Rp} \mathrm{2,767,874}$ \\
\hline & CitySibolga & $\mathrm{Rp} \mathrm{3,003,922}$ \\
\hline
\end{tabular}

Source: https://gajimu.com/garmen/gaji-pekerja-garmen/gaji-minimum/ump-umk-sumut

\section{Previous Research}

The research entitled Comparative Analysis Between Full Time Grab Driver Income and the City Regional Minimum Wage (Case Study in Medan City) was carried out inseparable from the existence of previous research conducted for study material and as well as for consideration and comparison material.

Research on JuventusBangkitWibowo (2018), on Comparative Analysis between Full Time Go-Jek Drivers and City Regional Minimum Wages Case Studies in the City of Yogyakarta, based on research conducted The presence of Grab can provide more income than the UMR that applies in Yogyakarta, with a total of 50 respondents where all respondents get income that exceeds the UMK in Yogyakarta. In this case the researcher can conclude that the income received by the respondents exceeds the size of the UMK in the city of Yogyakarta.

The difference between previous researches JuventusBangkitWibowo (2018), with current research, namely a different location, namely the previous research was located in Yogyakarta, where the culture of the people of Yogyakarta is more familiar with or often uses gojek in their activities, while in the city of Medan more use pedicabs and public transportation, in this study previously only used 50 respondents whereas in the current study using 60 respondents, previous researchers examined Go-jek driver income while researchers currently researching Grab driver income due to the location the researcher wants to research is close to Grab Station.

\section{IV.METHODOLOGY}

This research is a research that uses a case study research type. This research place was carried out in the vicinity of the HKBP Nommensen University Medan area. This research was conducted from February to March 2020 on Grab drivers who are waiting for consumer orders in Medan City. The population in this study were all Grab Fulltime drivers in the city of Medan. Because the researchers did not get a definite number of drivers, the sample was used in this study. Sampling is done using non probability sampling. In this study, the sample to be taken is a Medan City Grab driver who has a minimum work period of 6 months on the grounds that if less than 6 months is possible, the driver profession at Grab is only for a side job so that it is difficult to measure their income, satisfaction and performance as a Grab driver.

Researchers cannot access directly from the PT. Grab about the number of drivers available, so the researchers tried to find and determine the number of respondents themselves. Researchers determine the number of respondents as many as 60 people. The number of respondents as many as 60 people is assumed to be a small study, so it is considered quite representative.

The research subject here is the Grab Driver who works full-time as many as 60 respondents. The object of this research is the full time Grab Driver Income. This study uses a descriptive-comparative analysis method approach. This method is a research that is comparative in nature, which is carried out to compare the similarities and differences or more the properties and facts of the object under study based on a certain frame of mind. Comparative descriptive research is usually used to compare between 2 or more groups in a particular variable.

This method is carried out by comparing the revenue of the Grab Driver Fulltime with the UMK that has been determined by the Governor of North Sumatra in the Governor's Decree Number 188.44 / 674 / KPTS / 2019 stipulating the Provincial Minimum Wage (UMP) of North Sumatra in 2020. The Decree of the Governor of North Sumatra regarding UMP 2020 becomes reference in the preparation and determination of the Regency / City Minimum Wage (UMK) in North Sumatra for 2020 and is valid from January 1, 2020.

\section{RESEARCH RESULTS AND DISCUSSION}

Based on the results of the questionnaire that the male respondents were $95 \%$ while the female respondents were $5 \%$ who answered the questionnaire. Based on the results, it can be seen that the majority of 
respondents aged 25 to 34 years, namely a total of $41.67 \%$. The data above shows that the average respondent is in productive age, so that the respondent is considered able to work optimally. Based on the results, the majority of the latest education taken by Drivers is SMA / SMK as much as $65 \%$..

Table 3Distribution of Frequency of Income per Day

\begin{tabular}{|l|c|c|}
\hline \multicolumn{1}{|c|}{ Income } & Total & Percentage (\%) \\
\hline$\leq \operatorname{Rp~} 100.000$ & 33 & 55 \\
\hline $\operatorname{Rp~} 101.000 \mathrm{sd} 200.000$ & 10 & 16,67 \\
\hline $\operatorname{Rp} 201.000 \mathrm{sd} 300.000$ & 17 & 28,33 \\
\hline$>\operatorname{Rp} 300.000$ & - & - \\
\hline
\end{tabular}

In the table 3 the researcher uses a nominal value of Rp.101,000 to Rp. 200,000 which is based on the results of the interview for determining the low point and range.

Table 4Distribution of Frequency of Income per Month

\begin{tabular}{|l|c|c|}
\hline \multicolumn{1}{|c|}{ Income } & Total & Percentage (\%) \\
\hline$\leq \operatorname{Rp~3.222.556~}$ & 12 & 20 \\
\hline $\operatorname{Rp~3.222.557~sd~Rp~6.445.112~}$ & 40 & 66.67 \\
\hline $\operatorname{Rp} 6.445 .113 \mathrm{sd} \operatorname{Rp~9.667.669~}$ & 8 & 13,33 \\
\hline$\geq 9.667 .669$ & - & - \\
\hline
\end{tabular}

In the table 4 the researcher uses a nominal value of Rp. 3,222,556 which is the amount of UMK Medan City for determining the low point and range. In table 5, the majority of points obtained are 230 points, namely $55 \%$. In table 6 , the majority of bonuses based on points earned are IDR 50,000, namely $55 \%$.

Table 5Frequency Distribution of Number of Points Per Day

\begin{tabular}{|c|c|c|}
\hline Point & Total & Percentage (\%) \\
\hline 100 & 4 & 6,67 \\
\hline 160 & 14 & 23,33 \\
\hline 230 & 33 & 55 \\
\hline 390 & 9 & 15 \\
\hline
\end{tabular}

Table 6Frequency Distribution of Points Per Day Transaction Bonus

\begin{tabular}{|c|c|l|}
\hline Point & Total & \multicolumn{1}{|c|}{ Percentage (\%) } \\
\hline $\operatorname{Rp} 12.000$ & 4 & 6,67 \\
\hline $\operatorname{Rp} 30.000$ & 14 & 23,33 \\
\hline $\operatorname{Rp} 60.000$ & 33 & 55 \\
\hline $\operatorname{Rp~} 150.000$ & 9 & 15 \\
\hline
\end{tabular}

Table 7Distribution of Balance Deposit Frequency

\begin{tabular}{|l|c|l|}
\hline \multicolumn{1}{|c|}{ Deposit Balance } & Total & \multicolumn{1}{|c|}{ Percentage (\%) } \\
\hline Rp 100.000 & 52 & 86,67 \\
\hline $\operatorname{Rp~101.000~sd~Rp~200.000~}$ & 7 & 11,67 \\
\hline $\operatorname{Rp~201.000~sd~Rp~300.000~}$ & 1 & 1,67 \\
\hline$>\operatorname{Rp~300.000~}$ & - & - \\
\hline
\end{tabular}

In table 7, the researcher uses a nominal value of Rp. 100,000 which is based on the results of interviews for determining the low point and range.In table 8 the researcher uses a nominal value of Rp.10,000 which is based on a $70 \%$ revenue share for the company and the results of interviews for determining low points and ranges. In table 9 the researcher uses a nominal value of Rp. 15,000 which is based on the results of the interview for determining the low point and range. In table 10, the researcher uses a nominal value of Rp. 15,000 which is based on the results of interviews for determining the low point and range.In table 11 the researcher uses a nominal value of Rp. 25,000 which is based on the results of the interview for determining the low point and range. 
DOI: $\underline{10.51386 / 25815946 / i j s m s-v 3 i 6 p 108}$

Table 8Distribution of Average Frequency of Income Reduction

\begin{tabular}{|l|l|c|}
\hline \multicolumn{1}{|c|}{ Average Income Reduction } & \multicolumn{1}{|c|}{ Total } & Percentage (\%) \\
\hline Rp 10.000 & 42 & 70 \\
\hline Rp 20.000 & 11 & 18,33 \\
\hline $\operatorname{Rp} 30.000$ & 7 & 11,67 \\
\hline Rp 40.000 & - & - \\
\hline
\end{tabular}

Table 9Frequency Distribution of Petrol Costs per Day

\begin{tabular}{|l|c|c|}
\hline \multicolumn{1}{|c|}{ Petrol Cost Per Day } & Total & Percentage (\%) \\
\hline$\leq \mathrm{Rp} 15.000$ & 11 & 18,33 \\
\hline $\mathrm{Rp} 15.100 \mathrm{sd} \operatorname{Rp} 30.000$ & 42 & 70 \\
\hline $\operatorname{Rp} 30.100 \mathrm{sd} \operatorname{Rp} 45.000$ & 7 & 11,67 \\
\hline$>\operatorname{Rp} 45.000$ & - & \\
\hline
\end{tabular}

Table 10Frequency Distribution of Food Costs per Day

\begin{tabular}{|l|c|c|}
\hline Cost of meals per day & Total & Percentage (\%) \\
\hline$\leq \operatorname{Rp~} 15.000$ & 34 & 56,67 \\
\hline $\operatorname{Rp~} 15.100 \mathrm{sd} \operatorname{Rp} 30.000$ & 20 & 33,33 \\
\hline $\operatorname{Rp} 30.100 \mathrm{sd} \operatorname{Rp} 45.000$ & 6 & 10 \\
\hline$>\operatorname{Rp} 45.000$ & - & - \\
\hline
\end{tabular}

Table 11Frequency Distribution of Telecommunication Charges per Month

\begin{tabular}{|l|c|c|}
\hline $\begin{array}{c}\text { Telecommunication Charges per } \\
\text { Month }\end{array}$ & Total & Percentage (\%) \\
\hline$\leq \operatorname{Rp} 25.000$ & 2 & 3,33 \\
\hline $\operatorname{Rp} 25.100 \mathrm{sd} \operatorname{Rp~50.000}$ & 18 & 30 \\
\hline $\operatorname{Rp} 50.100 \mathrm{sd} \operatorname{Rp} 75.000$ & 29 & 48,33 \\
\hline$>\operatorname{Rp} 75.000$ & 11 & 18,33 \\
\hline
\end{tabular}

Table 12Frequency Distribution Comparison of Full Time Grab Driver Net Income and City Minimum

\begin{tabular}{|l|l|l|l|l|l|}
\hline No & Net Income & City Minimum Wage & Greater than (>) & Smaller (<) & Same (=) \\
\hline 1 & 4.725 .950 & 3.222 .556 & 1.503 .394 & - & - \\
\hline 2 & 4.725 .950 & 3.222 .556 & 1.503 .394 & - & - \\
\hline 3 & 7.499 .450 & 3.222 .556 & 4.276 .894 & - & - \\
\hline 4 & 2.021 .500 & 3.222 .556 & - & 1.201 .056 & - \\
\hline 5 & 8.687 .000 & 3.222 .556 & 5.464 .444 & - & - \\
\hline 6 & 3.413 .500 & 3.222 .556 & 190.944 & - & - \\
\hline 7 & 2.409 .450 & 3.222 .556 & - & 813.106 & - \\
\hline 8 & 6.474 .450 & 3.222 .556 & 3.251 .894 & - & - \\
\hline 9 & 3.850 .950 & 3.222 .556 & 628.394 & - & - \\
\hline 10 & 4.487 .000 & 3.222 .556 & 1.264 .444 & - & - \\
\hline 11 & 3.587 .000 & 3.222 .556 & 364.444 & - & - \\
\hline 12 & 3.850 .950 & 3.222 .556 & 628.394 & - & - \\
\hline 13 & 2.335 .950 & 3.222 .556 & - & 886.606 & - \\
\hline 14 & 10.375 .450 & 3.222 .556 & 7.152 .894 & - & - \\
\hline 15 & 3.925 .450 & 3.222 .556 & 702.894 & - & - \\
\hline 16 & 4.977 .450 & 3.222 .556 & 1.754 .894 & - & - \\
\hline 17 & 7.750 .950 & 3.222 .556 & 4.528 .394 & - & - \\
\hline 18 & 4.150 .950 & 3.222 .556 & 928.394 & - & - \\
\hline 19 & 4.750 .950 & 3.222 .556 & 1.528 .394 & - & - \\
\hline 20 & 3.850 .950 & 3.222 .556 & 628.394 & - & - \\
\hline 21 & 3.462 .450 & 3.222 .556 & 239.894 & - & - \\
\hline 22 & 3.850 .950 & 3.222 .556 & 628.394 & - & - \\
\hline 23 & 7.750 .950 & 3.222 .556 & 4.528 .394 & - & - \\
\hline 24 & 4.750 .950 & 3.222 .556 & 1.528 .394 & - & - \\
\hline 25 & 4.952 .450 & 3.222 .556 & 1.729 .894 & - & \\
\hline & & & & & - \\
\hline
\end{tabular}




\begin{tabular}{|l|l|l|l|l|l|}
\hline 26 & 3.825 .950 & 3.222 .556 & 603.394 & - & - \\
\hline 27 & 4.977 .450 & 3.222 .556 & 1.754 .894 & - & - \\
\hline 28 & 3.925 .450 & 3.222 .556 & 702.894 & - & - \\
\hline 29 & 4.725 .950 & 3.222 .556 & 1.503 .394 & - & - \\
\hline 30 & 7.125 .950 & 3.222 .556 & 3.903 .394 & - & - \\
\hline 31 & 10.125 .950 & 3.222 .556 & 6.903 .394 & - & - \\
\hline
\end{tabular}

Table 12Frequency Distribution Comparison of Full Time Grab Driver Net Income and City Minimum Wage (Continous)

\begin{tabular}{|c|c|c|c|c|c|}
\hline No & Net Income & City Minimum Wage & Greater than (>) & Smaller $(<)$ & Same (=) \\
\hline 32 & 6.599 .450 & 3.222 .556 & 3.376 .894 & - & - \\
\hline 33 & 3.698 .950 & 3.222 .556 & 476.394 & - & - \\
\hline 34 & 2.999 .450 & 3.222 .556 & - & 223.106 & - \\
\hline 35 & 10.063 .000 & 3.222 .556 & 6.840 .444 & - & - \\
\hline 36 & 4.413 .500 & 3.222 .556 & 1.190 .944 & - & - \\
\hline 37 & 4.713 .500 & 3.222 .556 & 1.490 .944 & - & - \\
\hline 38 & 4.487 .000 & 3.222 .556 & 1.264 .444 & - & - \\
\hline 39 & 3.825 .950 & 3.222 .556 & 603.394 & - & - \\
\hline 40 & 4.725 .950 & 3.222 .556 & 1.503 .394 & - & - \\
\hline 41 & 4.952 .450 & 3.222 .556 & 1.729 .894 & - & - \\
\hline 42 & 4.725 .950 & 3.222 .556 & 1.503 .394 & - & - \\
\hline 43 & 1.569 .450 & 3.222 .556 & - & 1.653 .106 & - \\
\hline 44 & 1.697 .450 & 3.222 .556 & - & 1.525 .106 & - \\
\hline 45 & 1.569 .450 & 3.222 .556 & - & 1.653 .106 & - \\
\hline 46 & 3.022 .000 & 3.222 .556 & - & 200.556 & - \\
\hline 47 & 1.582 .000 & 3.222 .556 & - & 1.640 .556 & - \\
\hline 48 & 3.899 .450 & 3.222 .556 & 676.894 & - & - \\
\hline 49 & 3.599 .450 & 3.222 .556 & 3768.894 & - & - \\
\hline 50 & 4.049 .450 & 3.222 .556 & 826.894 & - & - \\
\hline 51 & 4.275 .950 & 3.222 .556 & 1.053 .394 & - & - \\
\hline 52 & 4.275 .950 & 3.222 .556 & 1.053 .394 & - & - \\
\hline 53 & 5.699 .450 & 3.222 .556 & 2.476 .894 & - & - \\
\hline 54 & 2.549 .450 & 3.222 .556 & - & 673.106 & - \\
\hline 55 & 1.710 .950 & 3.222 .556 & - & 1.511 .606 & - \\
\hline 56 & 3.149 .450 & 3.222 .556 & - & 73.106 & - \\
\hline 57 & 2.848 .950 & 3.222 .556 & - & 373.606 & - \\
\hline 58 & 2.848 .950 & 3.222 .556 & & 373.606 & - \\
\hline 59 & 10.425 .950 & 3.222 .556 & 7.203 .394 & - & - \\
\hline 60 & 4.487 .000 & 3.222 .556 & 1.264 .444 & - & - \\
\hline
\end{tabular}

From table 12, the net income is greater than the UMK as many as 46 Grab drivers (76.67\%) while it is smaller than the UMK as many as 14 people $(23.33 \%)$.

\section{VI.CONCLUSIONS AND SUGGESTIONS}

Based on the results of data analysis and previous discussion, it can be concluded that the monthly income received by the majority of drivers is in the range of IDR 3,222,557 to IDR 6,445,112 as much as $63.33 \%$ and respondents who have an income smaller than the UMK are $23.33 \%$ and greater than MSE as much as $76.67 \%$. These results can be seen in Table 4.7 on page 55 and Table 4.15 on page 57 . In obtaining a net income that exceeds the UMK, the respondents must earn points so that they can cover the costs incurred. These results prove that the majority of income received by respondents exceeds the size of the UMK in Medan City. In this case the researcher can conclude that the income received by the respondents exceeds the size of the UMK in the city of Yogyakarta.

The limitation in this study is the way data collection is carried out by distributing questionnaires that ask for range income. So that the data about the income obtained is an estimate, then processed by finding the 
average of the range of answers to these questions. The form of this range was created because researchers did not know the daily income, which was always different. The number of Grab driver populations in Medan City was very large, namely $\pm 2,000$ drivers.

Based on the conclusions from the research results that have been stated above, suggestions can be given which are expected to help Grab drivers to take more opportunities so that the income they get increases, namely seeing opportunities or zones where the drivers will get more passengers, and, collect as many points as possible, and see when passengers use the Grab application a lot. Every job has its own strengths and weaknesses, both being a Grab driver, employee / employee, freelance worker, etc. Everyone should have a sense of responsibility and give more energy to the job in order to get satisfactory results.

\section{REFERENCES}

[1] AbdulaiSaliaBrima, (2020). An Assessment of the Conceptual Framework of Public Infrastructure and Its Impact on Economic Growth. International Journal of Science and Management Studies. Volume: 3 Issue: 3 May to June 2020. P 44 -48

[2] Permenakertrans No. 13 of 2012 concerning Components and Implementation of Stages of Achieving Decent Living Needs

[3] Rhardjo and Gudnanto, (2011). Non-Test Engineering Individual Understanding. Nora Media Enterprise. Kudus, p. 27

[4] Silaban, Adanan \& HamonanganSiallagan, (2012) Accounting Theory. Universitas HKBP Nommensen.Medan, pl. 198

[5] Silaban, Adanan \& MeilindaHarefa, (2019) Management Control System.Fakultas Ekonomi Universitas HKBP Nommensen. Medan, $\mathrm{p} 46$

[6] Sutrisno, Edy. (2010)Budaya Organisasi.Kencana Prenada Media Group, p 172 